\title{
Relationship Between Technological Hazards And Fishermen Vulnerability In Lake Victoria, Kenya
}

\author{
$1_{\text {dr. Amore Joy Atieno }}{ }^{2}$ Were Philip Onyango ${ }^{3}$ Dr. Okayo Joyce ${ }^{4}$ Dr. Abebe \\ Jack Onyisi \\ 5 Odinga Millicent Omondi \\ Masinde Muliro University Of Science And Technology Centre Of Disaster Management And Humanitarian \\ Assistance P.O Box 190-50100National Ministry Of Gender, Child And Social WelfareRepublic Of South \\ SudanMasinde Muliro University Of Science And TechnologyUn Women
}

\begin{abstract}
The Enactment Of The Lake Victoria Transport Act 2007 By The Government Of Kenya Was Expected To Improve Safety On The Lake. The Number of Maritime Casualties Would Reduce Significantly And That This Would Boost Fishermen Confidence On The Lake. Despite This Policy And Other Regional And International Legal Frameworks Being In Place, Fishermen In Lake Victoria Still Face A Myriad Of Technological Hazards That Enhances Their Vulnerability. In This Regard Need For Continuous Vulnerability Assessment And Mitigation Strategies Aimed At Reducing The Effects Of Maritime Disasters Cannot Be Under Scored. In Addition To This, It Is Imperative To Note That Effective Vulnerability Assessment Depends On Factors Such As Exposure, Sensitivity, And Adaptive Capacity of The Fishermen And Other Stakeholders. Conclusive Empirical Data On The Extent Of Fishermen Vulnerability To Technological Hazard In Lake Victoria Is Dearth Since Most Available Literature Are Based On Reports That Have Not Been Rigorously Tested. The Study Therefore Sought To Find Out The Extent To Which Technological Hazards Affect Fishermen On The Kenyan Side Of Lake Victoria. In Order To Determine Factors Contributing To Vulnerability Of Fishermen To Technological Hazards Correlation Research Design Was Used. The Study Population For This Study Comprised Of The Key Stakeholders In The Fishing Sector With A Sample Of 625 Respondents Who Included 401 Fishermen And 84 Key Informants And 140 Members Of A Focus Group Discussion. The Study Employed Questionnaires, Observation Checklist And Interview Schedule To Collect Data From The Respondents. The Study Found Out That The Type Of Lake Disasters Recorded An Insignificant Negative Correlation With Type Of Vessel, Frequency of Lake Disasters And Number Of People Involved In The Lake Disasters. Cross Tabulation Results Indicated That $94.3 \%$ Of The Lake Disasters Involved Boats, With 85.2\% Resulting In Drowning. 82.9\% Of The Respondents Indicated That Drowning Disasters Were Common On The Lake. The Study Recommends That Mitigation And Adaptation Measures Targeting Disaster Risk Reduction In Lake Victoria Should Focus On Addressing The Safety Of Vessels Particularly Boats And Perception Of Risk By The Fishermen.
\end{abstract}

Key Words: Technological Hazards, Vulnerability, Fishermen And Disaster

\subsection{Introduction}

Globally, The Fishing Industry Is Aimed At The Delivery Of Fish And Other Seafood Products For Human Consumption Or As Input Factors In Other Industrial Processes. According To Clay (2008), The World Harvest Of Fish In 2005 Consisted Of 93.3 Million Tonnes Captured By Commercial Fishing In Wild Fisheries, Plus 48.1 Million Tonnes Produced By Fish Farms. In China, Fishery Industry Has Played A More Important Role In The Country's Agriculture And The National Economy As Indicated By The Rapid And Continuous Growth Of People Living Standard. Since The End Of 1970s When China Started To Carry Out The Reform And Open-Door Policies, Fishery Sector Has Developed Rapidly And Achieved Great Results. The Fishery Output Was Ranked First In The World For Seven Years In Succession Since 1990, Making Up One Fourth Of The World Total. The Development Of Fisheries Has Also Helped To Create Job Opportunities For The Populations In China. As A Result The Government Has Always Attached Great Importance To The Application Of The Science And Technology To Fishery Production (Ringbom, 2008). Despite The Jobs And Livelihoods That The Fishing Industry Creates Globally, Most Research Is Silent On How The Same Jobs And Livelihoods Are Threatened By Technological Hazards, (Nashikura, 2010).

In Sub-Saharan Africa 400 Million People, Depend On Fish For Most Of Their Animal Protein Intake This Is Because Food Security Remains A Serious Problem In Africa. According To Yowa (2002), There Have Been 
Many Attempts To Promote Fishing As A Means To Address Food Security In Africa But With Limited Success. At Face Value, The Fishing Industry Provides Wages For Its Workers And Nutritious Food For Its Customers But It Is A Risky Investment For Fishermen. Fishing At Sea Is Probably The Most Dangerous Occupation In Africa. This Is Because Over 24,000 Fishermen Die Every Year While Using Sea Sites. Since Many People Are Depending On The Scarce Marine Resources, A Lost Vessel And A Lost Fisherman Have A Vital Impact On The Coastal Community. However, Despite Yowa (2002) Pointing Out How Vulnerable Fishing Is To Technological Hazards In Africa, He Remains Silent On The Coping Mechanisms Employed By The Fishing Community In The Region.In Kenya, Inland Fresh-Water Fisheries Are The Most Important, With Lake Victoria Dominating In Fish Production, Contributing Over 90\% Of The Total Fish Landings In The Period 1990-2008, (Nakyonyi, 2011). Lake Victoria Fishery Is Mainly A Commercial Fishery, With Artisanal Fishers, Working From Canoes Propelled Either Manually Or With Outboard Engines (Mark, 2013). Locally, Most Researchers Have Focused On The Commercial Value And Technology Employed By The Fishing Industry With Little Attention Given To The Technological Hazards Facing The Same Industry. The Study Seeks To Contribute To Local Literature Of The Vulnerability Of The Fishing Community On These Hazards.

In A Report On Lake Victoria Fisheries Indicates That Technical Hazards Have Become Part Of The Daily Experiences Of The Fishermen Community (Raymond, 2012). According To Nakyonyi, (2011), Vulnerability Of African Fishermen Integrates Many Environmental Concerns. In Lake Chad, Fishermen Are In Danger Of Being Struck By A Disaster Ranging From Floods To Warmer Seas And Higher Bleaching. In African Fishermen Are Extremely Vulnerable To Natural And Technological Hazards (Institute Of Law And Environmental Governance (Ileg), Kenya, 2005). According To Opere, (2004), Despite The SocioEconomic Benefits Of The Fishing Industry In Kenya, Fishermen Are Always In Danger Of Exposure To Natural And Technological Hazards That Cause Severe Damage Of Fishing Boats, Fishing Equipment, Supporting Facilities And Loss Of Life.

\subsection{Statement Of The Problem}

Despite The Existing Legislation, Lake Victoria Has Become A Pool Of Dangerous Water As Fishermen Are Highly Vulnerable To Technological Hazards. According To World Meteorological Organization, (2010) 5,000 People Are Killed Every Year On The Lake, Faulty Vessels , Lack Of Safety Kits, Victims Of Erratic Weather Conditions And A Mix Of Poor Communications And Lack Of Resources. The High Death Toll Makes The Lake Arguably The Most Dangerous Stretch Of Water In The World In Terms Of Fatalities Per Square Kilometre. In 2007 Fishermen On A Fishing Expedition Were Trapped By The Water Hyacinth Due To Heavy Rains Followed By Storms Making The Visibility And Navigation Of The Fishermen Difficult. There Are Many Widows In Lake Victoria Region Due To The Death Of Their Husbands In Fishing Accidents, Leaving Them To Support Families In An Area Where Jobs Are Few. According To Mclaughlin (2008), Fishermen Have Devised Ways Of Coping With Hazards Such As Large Waves By Not Going Out To Deep Water, Or Mooring Their Boats With Long Ropes During Small Tsunamis.

In Kenya There Is No Documentation On The Coping Strategies Employed By Fishermen In Relation To The Hazards Facing Them. It Is Against This Background That The Research Seeks To Investigate The Vulnerability Assessment Of Fishermen To Technological Hazards On The Kenyan Side Of Lake Victoria. Despite The Insights Offered In This Literature, No Research Has Critically Assessed The Vulnerability Of Fishermen To Natural And Technological Hazards And Coping Strategies On Kenyan Side Of Lake Victoria Hence The Study Seeks To Fill This Gap As A Result The Vulnerability Of Importance Resources Will Be Mitigated Or Eliminated Hence Improving Fishermen Safety In Lake Victoria.

\subsection{Research Objective}

The Research Was Guided By The Following Specific Objective;

a) To Determine The Technological Hazards Affecting Fishermen On The Kenyan Side Of Lake Victoria.

\subsection{Research Question}

Based On The Objectives Of The Study The Research Raises The Following Questions;

What Are The Technological Hazards Affecting Fishermen On The Kenyan Side Of Lake Victoria? 


\subsection{Literature Review}

\subsubsection{Technological Hazards}

Technological Hazards Is The Failure Of Manmade Systems, Which Occur Accidentally Or Deliberately, That Have The Potential To Cause Significant Loss Of Life, Cause Human Suffering, And Produce Significant Damage To Structures. There Is A Wide Range Of Hazards Of Technological Origin That Affect The Fishing Industry. These Are An Increasing Source Of Risk To Fishermen And Their Environment Around The World, (Heinrik, 2008). This Is An Effect Of The Globalization Of Production, An Increase Of Industrialization And A Certain Level Of Risk Connected With Sea Transportation And Waste Management. These Risks Are Associated With The Release Of Substances In Accident Condition Or With The Production Of Such Substances Under Certain Conditions As Fire, Substances Which Could Affect Fishermen Health, Fish, Sea Animals And Plants (Abila, 2005). Little Research Has Been Done To Assess The Vulnerability Of The Fishing Community To The Technological Hazards.

In A Study Conducted By Clay (2008), A Hazard Originating From Technological Includes Accidents, Dangerous Procedures, Infrastructure Or Specific Human Activities, That May Cause Loss Of Life, Injury, Illness Or Other Health Impacts, Property Damage, Loss Of Livelihoods And Services, Social And Economic Disruption, Or Environmental Damage.

Examples Of Technological Hazards Include Industrial Pollution, Nuclear Radiation In Water Bodies, Toxic Wastes, Dam Failures, Sea Transport Accidents, Fires, And Chemical Spills.Globally, Populations Depending On Fisheries And Aquaculture For Their Livelihoods Are Threatened By Technological Hazards Beyond Their Control, (Gul, 2010). Most Small-Scale Fishers And Fish Workers Live In Developing Countries And They Often Face A Multitude Of Problems That Increase Their Vulnerability To Hazards, Such As Pollution, Environmental Degradation, Overexploitation Of Resources, High Levels Of Accidents At Sea And Conflicts Within Industrial Fishing Operations. Many Coastal Communities Are Also Particularly Vulnerable To Hazards Resulting From Poverty And Food Insecurity. The Particular Characteristics Of The Fisheries Sector And The Livelihood Context Of Small-Scale Fishers And Fish Farmers And Their Communities Need To Be Clearly Understood In Order To Be Able To Provide Adequate Disaster Response In An Emergency Situation And To Help These People To Be Better Prepared For And Warned Of Potential Future Threats Through Preventive Disaster Risk Management. Rated Are Highest In The Small-Scale Fleet Operating Close To Shore (Yowa, 2002). This Study Has Adopted A Seamless Approach Of Establishing The Hazards The Fishing Community Faces, Their Vulnerability Levels As Well As Their Local Adaptive Mechanisms To Counter The Same.

Lake Victoria Is Historically Important To The Local Communities For Fisheries, Agricultural And Domestic Water Supply, (Kassim, 2012). In May 21, 1996 A Tragedy Occurred In Tanzania. About 500 People Were Feared Drowned In A Steamer Disaster On Lake Victoria. The Steamer, Mv Bukoba, Sank Near Bukoba With 600 People On Board; Most Of Them Were Feared Dead. Only 21 Bodies Were Recovered By The Tuesday Afternoon (Radio Tanzania) And Latest About 120 People Had Been Rescued That Far (Rodrigue, 2013). The Steamer Was From Bukoba Heading For Mwanza When It Sank About 30 Nautical Miles From Mwanza. It Developed Some Problems Near Mwanza And Almost Sank Before This Tragedy Occurred. The Bukoba Resumed Service Between Port Bell In Uganda, Kisumu In Kenya And Mwanza After The Revival Of East African Cooperation. This Sinking Was The Worst Ever Disaster In Lake Victoria. 26 People Drowned When The Boat They Were Travelling On From Lugala To Hama Island Capsized, The Boat Was Carrying 50 People Loaded With 200 Crates Of Beer, 190 Sacks Of Maize Flour And Over 80 Sacks Of Charcoal. Ugandan Radio Network Statistics Indicates That There Has Been Drastic Increase In The Number Of Deaths On The Lake. According To Raymond (2012), 109 Were Killed In Eight Different Accidents In Suba, While The Neighbouring District Witnessed Eight Deaths In Five Boat Accidents. In 2011, A Number Of Tragedies Occurred In Lake Victoria Among Them. A Boat Accident, After A Motor Boat In Kisumu To Remba Island Lost Control And Rammed Into A Fishing Boat, Two Fishermen In A Boat Perished, Two Others Were Rescued. A Fisherman Drowned In The Lake While Fighting With His Workmate (Yowa, 2002). Most Focus By Researchers Has Been On The Risks Associated With Hazards On The Lake. Little Attention Has Been Given On How To Address The Risks And That What This Study Seeks To Solve Through Assessment Of Vulnerability To These Hazards.

Fishermen In The Lake Suffer From Among Others Hazardous Safety And Or Security. 5000 People Are Estimated To Drown Annually In The Lake As A Result Of Maritime Accidents. (Mark, 2013) States That Disaster Frequently Strike Fishermen In The Lake Victoria. For Example The Passenger Vessel M/V Bukoba Capsized In 1996 With The Loss Of Over 500 Lives. The Wagon Ferry M/V Kabalega Collided With A Sister Vessel Mv/ Kaawa And Sank In 2005. Cargo Vessel Mv Nyamageni Sank In 2006. More Recently, The Following Incidents Have Been Reported; 18 Tanzanian School Children Drowned When 
Their Vessel Flipped In Strong Winds On August 05, 2010. 28 People Are Feared Dead After Their Ferry Capsized In Bad Weather Near Entebbe On July 21, 2011.

Nakyonyi (2011) Says That This Is A Crisis And The Need For Improved Safety Standards Cannot Be Overruled. The Issue Of Disaster Response Is Very Critical In The Prevention Of Extensive Negative Effects Of Disasters. This Can Be Done Through The Development Of Comprehensive Disaster Emergency Plans. Make Sure That Early Warnings Reach And Are Understood By The Most Vulnerable People; They Need To Know What To Do, Where To Go, And How To Protect Themselves.It Can Also Be Done By Provision Of Food To Communities With Emergency Material Such As Water Purification Tablets, Jerry Cans, Chain Saws, Lanterns, Plastic Sheeting, First Aid Suppliers And Venerators (Owili, 2006). Dedicate Vacated Areas For Specific Uses (Such As Parks Or Football Fields) When Moving People Out Of Flood Plains. Build Houses And Infrastructure To Withstand Future Disasters Such As Provide Roofs With Straps To Protect Against Hurricanes, Use Steel Reinforcements At The Corners Of A House To Make It Earthquake Resistant. Provide Disaster Victims With Cash Support To Purchase Their Own Supplies, Shelter Rather Than Receive Items In Kind Which Might Not Be Appropriate. Gender Differences Should Also Be Considered When Designing The Response To Disaster Often Affect Men And Women Differently. Safety Standards Cannot Be Improved Without A Clear Understanding Of The Vulnerability Conditions As Well As The Local Adaptive Capacities. This Study Provides An Avenue For Improvements In The Safety Standards By Building On Local Coping Mechanisms.In Summary, The Global Trends In Technological Disaster Occurrences And Impacts Suggest Several Important Patterns Of Vulnerability Among People And Places, At The Same Time That They Mask Considerable Geographic Variation. The Reviewed Studies Reveal That 5000 People Are Estimated To Drown Annually In Lake Victoria As A Result Of Maritime Accidents. Even Though A Comprehensive Analysis Is Given On How Dangerous Fishing In Lake Victoria And Other Parts Of The World Is, The Studies Fail To Assess The Hazards Facing Fishermen On The Kenyan Side Of Lake Victoria. Therefore The Research Seeks To Evaluate Both Natural And Technological Hazards Facing Fishermen In Lake Victoria.

\subsubsection{Vulnerability Of Fishermen To Technological Hazards}

The World Conference On Disaster Reduction In The Fishing Industry Held From $18^{\text {th }}$ To $22^{\text {nd }}$ January 2005 In Kobe, Hyogo Japan, Adopted A Framework For Action 2005-2015; For Building The Resilience Of Nations And Fishing Communities To Disasters. The Conference Provided A Unique Opportunity To Promote A Strategic And Systematic Approach To Reducing Vulnerabilities And Risks To Hazards. It Underscored The Need For, And Identified Ways Of, Building The Resilience Of Nations And Communities To Disasters (Gallopín, 2006). It Was Observed That Disaster Loss Is On The Rise With Grave Consequences For The Survival, Dignity And Livelihood Of Individuals, Particularly The Poor And Hard Won Development Gains. It Was Against This Background That This Study Sought To Assess The Vulnerabilities And Local Capacities Of The Fishing Community To The Hazards That Face Them So As To Provide A Starting Point For Enhancing Their Safety By Building On Local Resilience.According To Byron (2004), Poverty Is A Main Cause Of Vulnerability In Many Parts Of The World And There Is A Clear Link Between Disaster Risk And Development. Over The Last Decade, An Average Of 44 People Were Killed Per Natural Disaster In Countries With A High Human Development Index (United Nations Development Programme Human Development Index), While The Average Death Toll In Countries With A Low Index Was 300 People Per Event. To Reduce Disaster Risk, It Is Important To Reduce Exposure, Keep People As Far Away From The Hazard As Possible And Minimize The Level Of Vulnerability. This Can Be Achieved By Removing The Underlying Causes Of The Vulnerability Through, For Example, Poverty Alleviation (Press, 2003). Vulnerability And Exposure Can Also Be Reduced By Preparedness And Early Warning Mechanisms. In Line With This The Also Study Sought To Evaluate The Factors Of Vulnerability Affecting The Fishing Community In Lake Victoria, (Kenya Metrology Department, 2012).Raymond (2012) Indicates That Most Of The Inhabitants Of The Lake Victoria Basin (Lvb) Are Farmers (Average Of 73\% For Kenya). Despite The Abundant Land And Fisheries Resources The Inhabitants Of The Lake Region Are Among The Poorest In The Region. For Instance An Average Of $41.3 \%$ Of The Lake Victoria Basin (Tanzania) Live Below The Basic Needs Poverty Line While Those On The Kenya Side Are 39\% And The Uganda Side 34\%. Other Demographic Aspects Considered Include Gender Especially The Way Men And Women Work Together And The Division Of Labour And How They Share Benefits From Their Contribution To Production. Marital Status Is Looked At In Terms Of The Composition Of Households, Whether Polygamous Or Monogamous. The Types Of Households Do Have Implications On Cultural Values And Beliefs. For Instance Polygamy Is Taken To Be A Sign Of Wealth And High Social Status In Some Communities. (Mark, 2013) Argues That Population Density Has Been Increasing At A Tremendous Rate In The Lake Victoria Basin Tanzania Side With The Highest Rate Of Population Increase Witnessed Between 1988 And 2002 (152\% Increase In Population Density For Mwanza, 153\% For Kagera, 157\% For Shinyanga And 140\% 
For Mara). The Studies However Do Not Demonstrate The Link Between Some Of The Factors Of Vulnerability Being Highlighted With The Technological Hazards In Lake VictoriaMoreover This Coincided With The Time Of The Nile Perch Boom Period And "Gold Rush" Period, Where An Influx Of People Flooded The Lakeshore Towns Of Mwanza Where There Are More Fish Processing Plants And Fishing Business Is Higher. Gold And Diamond Resources Attracted People To Shinyanga And Mwanza Regions During This Period Due To Liberalization Policies, Which Made These Resources Accessible By Small Scale As Well As Large Scale Mining Companies. Occupational Activities Of Lvb (Lake Victoria Basin) Includes: Fishing, Farming, Bee Keeping, Trading Activities, Quarrying And Sand Mining And Mining Of Gold And Other Minerals (Gallopín, 2006). The Studies Do Not Demonstrate If Their Exist Associations Between Vulnerability Of Fishermen To Technological Hazards With Other Occupational Activities Within Lake Victoria.Nakyonyi,(2011) Populations Depending On Fisheries And Aquaculture For Their Livelihoods Are Threatened Not Only By Technological Hazards But Also By Human-Induced Events And Developments Beyond Their Control. Most Small-Scale Fishers And Fish Workers Live In Developing Countries And They Often Face A Multitude Of Problems That Increase Their Vulnerability To Hazards, Such As Pollution, Environmental Degradation, Overexploitation Of Resources, High Levels Of Accidents At Sea And Conflicts Within Industrial Fishing Operations. Many Coastal Communities Are Also Particularly Vulnerable To Hazards Resulting From Poverty And Food Insecurity. The Particular Characteristics Of The Fisheries Sector And The Livelihood Context Of Small-Scale Fishers And Fish Farmers And Their Communities Need To Be Clearly Understood In Order To Be Able To Provide Adequate Disaster Response In An Emergency Situation And To Help These People To Be Better Prepared For And Warned Of Potential Future Threats Through Preventive Disaster Risk Management (Drm). Rated Are Highest In The Small-Scale Fleet Operating Close To Shore (Mark, 2013). Despite The Information Offered In This Literature, The Studies Fail To Explore The Vulnerability Of Fishermen In Lake Victoria To Technological Hazards.Disaster Risk Reduction TheoryThe Study Adopted Disaster Risk Reduction Theory. According To This Theory In The RiskHazard Framework, The Pressure And Release Model Explain Vulnerability As The Result Of Two Opposing Forces: Hazard And Vulnerability. Whereas Hazard Refers To Natural Events That Vary According To Intensity, Severity And Spatial Scale (Wisner Et Al, 2004) Distinguish Between Three Levels Of Factors That Generate Vulnerability According To Their Level Of Specificity. Root Causes Which Encompass General And Widespread Processes In A Society Are Spatially Or Temporally Distant To The Current Risk. These Distant Are Related To Basis Societal Processes And Characteristics As Beliefs, Cultural Assumptions, Norms And Values.According To Wisner, 2004 Especially Economic, Demographic And Political Process Contribute To Increasing Vulnerability Since They Effect The Allocation Of Resources And Power Among People. Dysfunction Of The State Might Also Give Rise To Vulnerability. Due To This Focus On These Distant And Subtle Processes The Par-Model Requires Sound Research About Local And Historic Conditions. The Effects Of Root Causes Are Translated By Dynamic Pressures Into More Immediate And Contemporary Unsafe Conditions.The Patterns Of Tangible Resources (E.G. Cash, Shelter, Food Stocks, And Agricultural Equipment) And Intangible Resources (Networks Of Support, Morale, Ability To Function In A Crisis, Knowledge Sharing Regarding Survival Strategies) Serve As A Bridge Between The Par And The AccessModel. According To Nakyonyi (2011), A Hazard, As Presented In The Risk Reduction Theory Refers To A Potential Damaging Physical Event Or Human Activity That May Cause Socioeconomic Or Environmental Degradation. On The Other Hand, The Level Of Vulnerability Refers To The Condition Which Increases The Susceptibility Of An Individual Or A Community To The Impact Of Hazards.

Therefore, The Disaster Risk Reduction Provides A Useful Model For Assessing The Relationship Between Natural And Technological Hazards (Independent Variable) And Vulnerability Of Fishermen (Dependent Variable). It Provides A Trace Of The Connections That Link Natural And Technological Hazards With A Series Of Factors That Generate Vulnerability. In Addressing The Issue Of Vulnerability Of Fishermen The Study Is Able To Derive Useful Insights Into Key Sources Of Vulnerability To Potential Natural And Technological Hazards And To Consider Possible Ways Of Enhancing Mitigation And Preparedness Of Fishermen (Intervening Variable) To Minimize Vulnerability.In Assessing Vulnerability Of Fishermen, The Study Focuses On Three Dimensions: Impact Of Hazard, Vulnerability Of Fishermen And Ways Of Enhancing Mitigation And Preparedness Of Fishermen That Produce Resilience.

\subsection{Conceptual Framework}

The Concept Framework Adopted For This Study Is As Explained In Figure 1

\section{Independent Variable \\ Dependent Variable}




\section{Technological Hazards}

- Overloading of vessels

- Poor conditions of equipment

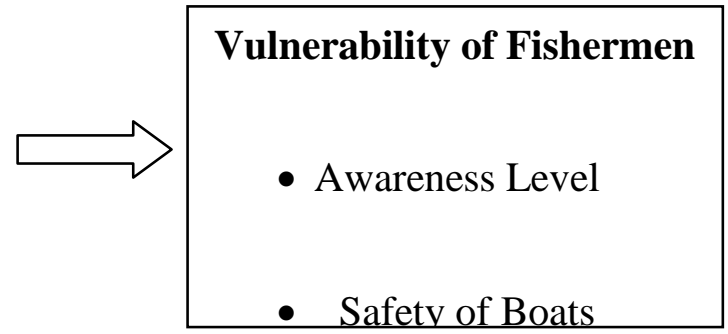

Source: Author, (2014)

Figure 1, Conceptual Framework Showing Relationships Between Technological Hazards And Vulnerability Of Fishermen

\subsection{Research Gap}

In The Literature That Has Been Reviewed It Is Evident That Fishing Can Make Substantial Improvements To Livelihood, Foster Economic Growth And Improve Food Security Without Compromising Ecosystem Services Within The Lake Region And In Kenya (Clay, 2008). It Is Also Indicated That There Are Problems Facing Fishermen And Hindering The Growth And Development Of The Fishing Industry, (Kisusu Et Al, 2012). The Studies Indicate That Legal And Regulatory Framework Exist Both At Regional And Local Levels To Streamline The Fishing Industry. Regionally, The Lake Victoria Transport Act 2007 Was Enacted To Provide Mechanisms That Will To Enhance Maritime Safety On The Lake. The Act Has Provisions For Construction, Surveying, Registration And Licensing Of All Vessels Used On Lake Victoria, For Ensuring The Safety Of Fishermen, Passengers, Cargo As Well As Standards For Competency Of Crew. Consequently, The Global Trends In Disaster Occurrences And Impacts Suggest Several Important Patterns Of Vulnerability Among People And Places, At The Same Time That They Mask Considerable Geographic Variation. Despite The Insights Offered In This Literature, No Research Has Critically Assessed The Vulnerability Of Fishermen To Technological Hazards And To Establish The Coping Strategies On Kenyan Side Of Lake Victoria Hence The Study Sought To Fill This Gap.

\subsection{Methodology}

\subsection{Research Design}

The Study Used Correlation Design To Achieve The Specific Research Objective. According To Godwin (2006) Survey Research Design Involves Either Identifying The Characteristics Of An Observed Phenomenon Or Exploring Possible Correlations Among Two Or More Phenomena.

\subsection{Study Population}

The Study Population For This Study Comprised Of The Key Stakeholders In The Fishing Sector Who Are Vulnerable To The Technological Hazards. These Included 40,078 Fishermen Spread Across The Fourteen Sub-Counties In Along Lake Victoria On The Kenyan Side. Key Informants Included 14 Beach Management Unit Managers, 14 Police Officers, 14 Sub-County Health Officers, 14 Emergency Management Officers, 14 Village Elders And 14 Red Cross Officers. The Study Also Included 14 Focus Group Discussions Each Group Will Consist Of 10 People. Therefore The Total Population For This Study Was 40,302.

\subsection{Sampling Size And Sampling Procedure}

The Target Population Was Heterogeneous And Therefore Both Non Probability And Probability Sampling Approaches Were Used. The Fourteen Sub-Counties Were Purposively Sampled Because They Border Lake Victoria On The Kenyan Side. Key Informants Were Also Purposively Sampled In Each Of The Fourteen Sub-Counties. To Select Fishermen The Researcher Employed Both Proportionate And Simple Random Sampling Technique. Proportionate Sampling Was Used To Determine The Number Of Fishermen From Each Registered Beaches, Then Simple Random Sampling Was Used To Sample The Fishermen For The Study.According To Mugenda And Mugenda (2006) For A Population Of 1-100 A Sample Of 100\% Was Used As A Sample Size, For A Population Of 100-1000, 30\% Of The Population Was Used As A Sample Size, For A Population Of 1000-10000, 10\% Of The Population Was Used As A Sample Size While For A Population Of 10000-100000, 1\% Of The Population Was Used As A Sample Size. After Careful Consideration The Researcher Picked A Sample Of 625 Respondents Which Include 401 Fishermen And 84 Key Informants And 140 Members Of A Focus Group Discussion. 


\subsubsection{Data Collection Instruments}

The Study Employed A Number Of Tools Including Questionnaires, Interview Guides And Observation Checklists. These Tools Were Used To Collect Primary Data From Respondents. Secondary Data Were Collected From Secondary Sources Such As Reference Books, Journals, Indexes, Abstracts And Government Publications.

\subsubsection{Questionnaires}

Uma (2003) Defines A Questionnaire As A Formulated Written Set Of Questions To Which Respondents Record Their Answers Within Closely Defined Alternatives. Most Variables In The Questionnaire Were Closed With A Few Open-Ended Questions. This Was Meant To Facilitate Easy Coding And Analysis. These Instruments Were Used To Collect Data From Fishermen. The Questionnaires Were Pre-Tested On A Pilot Basis Before Data Collection Commences.

\subsubsection{Interview Guides}

The Study Used Interview Guides To Gather Information From Key Informants And Focus Group Discussions. The Interviewer Had A List Of Predetermined Probing Questions Directed To Respondents. These Tools Consisted Of Open Ended Questions, Which Gave The Researcher A Complete And Detailed Understanding Of The Issues Under Research. They Also Gave Respondents Freedom To Respond In Whatever Way They Wanted. The Instrument Was Used To Source Data From Bmus, Police Officers, SubCounty Health Officers, Emergency Management Officers, Village Elders And Red Cross Officers.

\subsubsection{Observation Checklists}

The Researcher Observed Various Variables Of The Study Guided By An Observation Checklist. The Researcher Observed Equipment Used By Fishermen While At Work And Other Issues That Will Be Relevant For This Study. The Information Obtained Was Used To Verify And Confirm The Information Collect From Questionnaires Responses And Interviews With Key Informants (Mugenda \& Mugenda, 2003).

\subsection{Data Collection Procedures}

The Researcher Contracted A Team Of Five Trained Research Assistants Who Understand The Local Languages Of The Study Population. The Team Worked Under The Leadership Of The Main Researcher. The Use Of Locally Trained Research Assistants Decreases The Potential Of Bias. Therefore, Research Assistants Assisted In Administration Of The Instruments. The Respondents Were Given Enough Time To Respond To All The Questions.

\subsection{Data Analysis And Presentation}

Kombo And Tromp (2006) Described Data Analysis As The Process Through Which The Data That Has Been Collected Is Examined. It Involves Uncovering Underlying Structures, Extracting Important Variables, Detecting Any Anomalies And Testing Any Underlying Assumptions. It Involves Scrutinizing The Acquired Information And Making Inferences. Information Collected From The Respondents Was Coded For Analysis Using Statistical Package For Social Scientists (Spss) Version 16.Quantitative Data Was Analysed Using Descriptive Statistics Including Frequencies, Averages, And Percentages And The Results Will Be Presented Through Tables And Figures. The Researcher Also Conducted Spearman Rho Correlation To Establish The Strength And Direction Of Relationships Between The Variables. Qualitative Data Which Was Mainly Collected By Open Ended Questions Were First Classified On The Basis Of Common Attributes Then Tallied To Obtain Statistical Frequencies, Tabulated And Finally Analysed Using Descriptive Statistics. According To Kothari (2010), This Helps To Collapse Large Volume Of Qualitative Data In Numerical Form For Ease Of Statistical Interpretation.

Pearman's Rank Order Correlation Was Calculated For Ranked Coping Strategies, Based On The Following Formula.

Equation 4

$\mathrm{R}=1-\frac{6 \sum D^{2}}{N\left(N^{2}-1\right)}$

The Correlation Coefficient Computed Between Variables Was Interpreted By Comparing Its Magnitude With Its Probable Error. The Probable Error Of The Coefficient Of The Correlation Was Obtained Using A Formula:

P.E.R $=0.6745 \frac{1-r^{2}}{\sqrt{N}}$ 
Where:

P.E.R = Probable Error

$\mathrm{R}=$ Coefficient Of Correlation, And

$\mathrm{N}=$ The Number Of Pairs Or Observations Used In Derivations Of R.

When R <P.E.R There Is No Evidence Of Correlation, Meaning The Value Of R Is Not Significant $(\mathrm{P}>0.05)$.

On The Other Hand, When The Value Of R > 6 P.E.R The Coefficient Of Correlation Is Practically Certain $(\mathrm{P}<0.05)$ (Gupta, 2008). 


\subsection{Findings}

4.2 Response Rate

From The Data Collected, Out Of The 401 Questionnaires Administered All Were Filled And Returned. This Represented 100\% Response Rate, Which Is Considered Satisfactory To Make Conclusions For The Study. According To Fisher In Mugenda And Mugenda (2003) A 50\% Response Rate Is Adequate, $60 \%$ Good And Above 70\% Rated Very Good. This Corroborates Bailey (2000) Assertion That A Response Rate Of 50\% Is Adequate, While A Response Rate Greater Than 70\% Is Very Good.This Implies That Based On This Assertion; The Response Rate In This Case Of 100\% Is Very Good. This High Response Rate Can Be Attributed To The Data Collection Procedures, Where The Researcher Pre- Notified The Potential Participants And Applied The Drop And Pick Method Where The Questionnaires Were Picked At A Later Date To Allow The Respondents Ample Time To Fill The Questionnaires.

\subsection{Reliability}

A Pilot Study Was Carried Out In Order To Determine Reliability Of The Questionnaires. Reliability Of The Questionnaires Was Then Evaluated Through Cronbach's Alpha Which Measures The Internal Consistency. The Alpha Measures Internal Consistency By Establishing If Certain Item Measures The Same Construct. Nunnally (1978) Established The Alpha Value Threshold At 0.7 Which The Study Benchmarked Against. Cronbach Alpha Was Established For Every Objective In Order To Determine If Each Scale (Objective) Would Produce Consistent Results Should The Research Be Done Later On.

Table 1 Shows That All The Scales Were Significant, Having An Alpha Above The Prescribed Threshold Of 0.7. Factors Contributing To Vulnerability Had The Highest Reliability $(A=0.833)$ Followed By Natural And Technological Hazards $(A=0.819)$, While Theeffectiveness Of Coping Strategieshad The Lowest $(A=0.781)$. The Study Thus Found That The Analysis Was Reliable And Could Be Used For Further Investigation.

Table 1 Reliability Coefficients

\begin{tabular}{lll}
\hline Scale & Cronbach's Alnha & Number Of Items \\
Technological Hazards & 0.819 & 20 \\
Factors Contributing To Vulnerability & 0.833 & 20 \\
\hline
\end{tabular}

Source: Pilot Study, 2014

\subsection{Technological Hazards Affecting Fishermen On The Kenyan Side Of The Lake}

Technological Hazards, Which Result From Poor Or Lack Of Skills, Which Are Necessary For The Operations Of The Fishing Activities At The Lake. From Figure4.4, Poor Weather Condition Was The Main Hazard Faced By Fisherman On The Lake. Although It Contributes To The Hazards At 80\%, Technological Hazards Cannot Be Ignored Because They Have A Significant Contribution To The Major Disasters Encountered On The Lake. Technological Hazards Are Discussed In Figure 4.8.

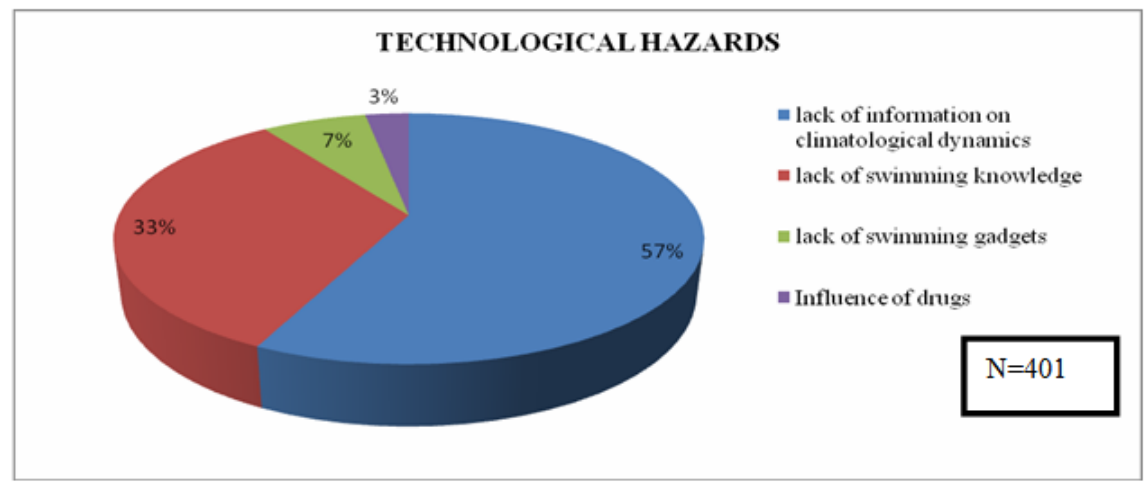

Figure 2: Causes Of Technological Hazards On Lake Victoria Kenya Source: Field Data 2014.

From The Figure 2, Majority Of The Respondents (57 \%, N=200) Respondents Feel That Lack Of Climatological Information Is A D Hazard Itself. Fishermen Do Fishing Without Putting Much Consideration On Climatic Changes. 33\% (116) Of The Respondents Said That Lack Of Swimming Knowledge Was S A Major Technological Hazard On The Lake. The Respondents Said That There Is No Station Or Institutions Around Their Areas Which Could Train Them On How To Swim, In Cases Of Hazards Or Rescue Missions.Lack Of Swimming Gadgets Was Another Cause Of Hazard At 3.8\%. This Implies That 
Quite A Number Of Respondents Lack Swimming Gadgets Like Reflector Jackets, Alarms. Cumulatively, It Can Be Said That There Are No Teams Equipped With Knowledge And Equipment, Which Could Be Of Use When It Comes To Rescue Of Life In The Event Of Capsizing Boats.It Was Also Noted From The Respondents, That Some Fishermen Go To The Lake While Drunk. This Increases The Vulnerability Chances Of One To Hazards. 0.2\% From The Respondents Agreed That Most Disasters In The Lake Are Brought About By The People Who Go To The Lake For Either Fishing, Sand Harvesting, Or For Transport While Drunk In Lake Disasters.It Was Also Noted From The Respondents, That Some Fishermen Go To The Lake While Drunk.

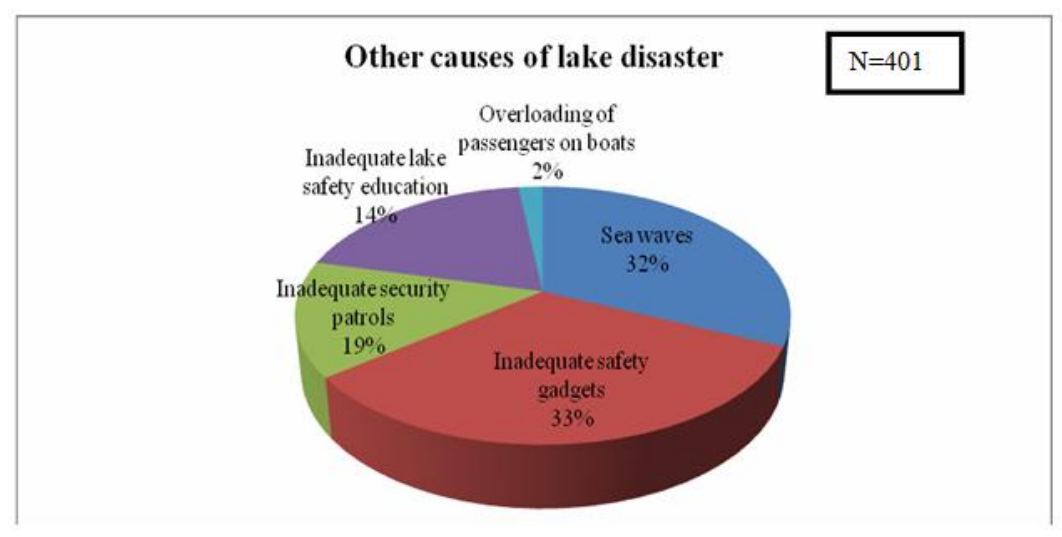

Figure 3: Other Causes Of Disaster On Lake Victoria Kenyan Side Source: Field Data 2014.

The Key Informants Attribute Lake Disasters To Inadequate Safety Gadgets At 33\%, Sea Waves At 32\% Inadequate Security Patrols At 19\% Inadequate Safety Education At 14\% And Overloading Of Passengers And Luggage On Boats At 2\%. From The Fishermen Interview, Overloading Did Not Come Out As A Hazard Factor. This Can Be Generally Concluded, That There Are No Proper Scientific Ways, In Which The Boats Operating On The Lakes Are Able To Determine The Maximum Weight Their Boats Can Accommodate

\subsection{Type Of Vessel Involved In Disaster}

The Commonly Used Vessel For Fishing, Sand Harvesting And Travelling On The Lake Victoria Are Wooden Boats. They Are The Most Involved In Lake Disasters. The Study Sought To Establish The Type Of Vessels That Were Involved In Lake Disasters And The Results Are Displayed In Figure 4.
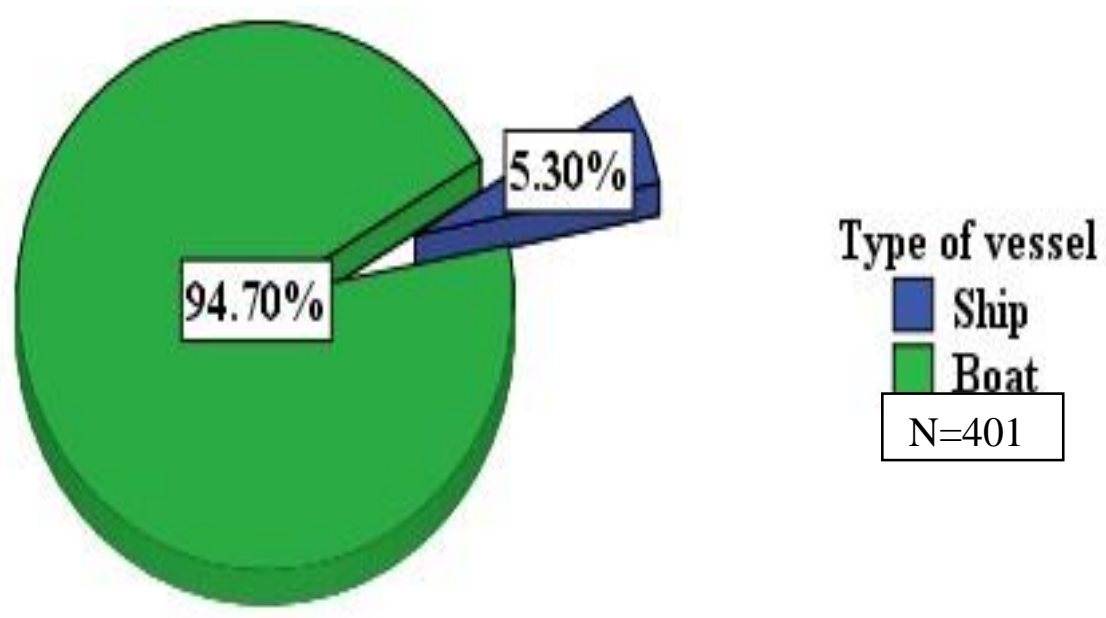

Figure 4: Type Of Vessels Involved In Disasters On The Lake Source: Field Data 2014.

From Figure 4, Most Respondents (94.70\%) Indicated That Boats Were Involved In Disasters While (5.30\%) Indicated Ships. Ships Used On This Lake Are The Motor Type Commonly Referred To As Ferry.

According To Raymon \& Hans, (2007), Fishers Are Highly Dependent On Fishing For Their Livelihood With Little Possibility Of Finding Alternative Employment. Their Access To Land Is Generally Limited And Their Assets, In The Form Of Boats And Gear, Are More Exposed To Natural Hazards And Hence More Easily Lost Than Land-Based Property. According Raymon (2012), The Lake Is Also Extensively Used For Transport 
And Trade Purposes. There Are A Few Big Ferries, Transport Boats And Oil Tankers, But Most Of The Goods Transported Between Landing Sites Is Carried Out By Big, Open, Wooden Motorized Boats (Between 4 And 10 Tons).Wooden Boats Are Commonly Used On Lake Victoria By Farmers Because Of Their Low Cost Of Purchase, Maintenance And Access To The Lake. Wooden Boats In Most Cases As Taken By The Fishermen On The Lake Shores, They Do Not Need Specialized Training For One To Operate. They Are Generally Said To Be Economically Sensitive To The Local Dwellers Along The Lake.

A Chi Square Test Was Further Performed To Assess The Relationship Between The Type Of Vessel Involved In Lake Disaster And The Vulnerability Of Fishermen. The Table Below Presents The Findings.

Table 3: Chi-Square Test: Type Of Vessel Involved In Lake Disaster And The Vulnerability Of Fishermen

\begin{tabular}{|l|l|l|l|}
\hline & Value & Df & Asymp. Sig. (2-Sided) \\
\hline Pearson Chi-Square & 14.01039 & 9 & 0.0007 \\
\hline Likelihood Ratio & 11.054292 & 9 & 0.0010 \\
\hline Linear-By-Linear Association & 0.00417 & 1 & 0.0429 \\
\hline N Of Valid Cases & 162 & & \\
\hline
\end{tabular}

A4 Cells (25.0\%) Have Expected Count Less Than 5. The Minimum Expected Count Is 3.71.

A P-Value Of 0.0007 Shows A Strong, Significant, Positive Relationship Between The Types Of Vessel Involved In Lake Disaster And The Vulnerability Of Fishermen In The Study Area. Therefore Basing On These Findings The Study Deduces That There Exists A Strong Positive Relationship Between The Type Of Vessel Involved In Lake Disaster And The Vulnerability Of Fishermen.

\subsection{Causes Of Lake Disasters}

The Wooden Boats Used On The Lake Are Open Channel Where, Sometimes If The Rain Falls While The Transport, Fishing Or Sand Harvesting Operation On The Lake Are Underway, The Vessel Collects More Water Inside It. Accumulation Of Water In A Wooden Boat Is A Disaster In Waiting; A Hazard. This Causes An Inevitable Instability Of The Boat Where Toppling Is Easy.

The Beach Management Units Also Attribute Accidents To Overloading Of The Boats. This A Factor That Was Overlooked By The Fishermen Themselves, Because Possibly They May No Understand The Maximum Load Weight A Boat Deserves.Generally It Can Be Concluded That A Wooden Boat, Is Itself A Potential Hazard That The Users, Who Are Commonly Fishermen, Are Vulnerable To. This Is Certainly So Because Of Its Small Size, Some Are Too Old And Therefore Leaking At The Bottom, Inexperienced And Unskilled Operators, And Lack Of Any Adaptively To Adverse Weather Conditions

Table 4: Causes Of Lake Disaster

\begin{tabular}{|l|l|l|}
\hline Cause Of Disaster & Frequency & Percent (\%) \\
\hline Weather & 352 & 87.7 \\
\hline Lack Of Swimming Knowledge & 25 & 6.3 \\
\hline Lack Of Swimming Gadgets & 20 & 5.1 \\
\hline Hippos Knocked The Boat & 4 & 0.9 \\
\hline Total & $\mathbf{4 0 1}$ & $\mathbf{1 0 0 . 0}$ \\
\hline
\end{tabular}

Source: Field Data 2014.

Results In Table 5.2 Illustrate That Most Causes Of Lake Disasters $352(87.7 \%)$ Was Associated With Weather, $25(6.3 \%)$ Was Associated With Lack Of Swimming Knowledge, $20(5.1 \%)$ Indicated Lack Of Swimming Gadgets While 4(0.9\%) Indicated Hippos Knocked The Boats. Safety Is One Of The Biggest Problems Affecting Both Users And Operators And Influencing Their Use Of Water Transport. There Are Unique Weather Dynamics That Continuously Threaten Air And Marine Navigation Over The Lake And Its Basin. The Region Around The Lake Has The Highest Occurrence Of Hailstorms And Thunderstorms In The Eac Region. The Most Important Navigation Hazards Are Storms, Strong Winds And Strong Waves.

The Researcher Further Enquired The Causes Of Lake Disasters From The Key Informants. The Results Are Displayed In Figure 5. 

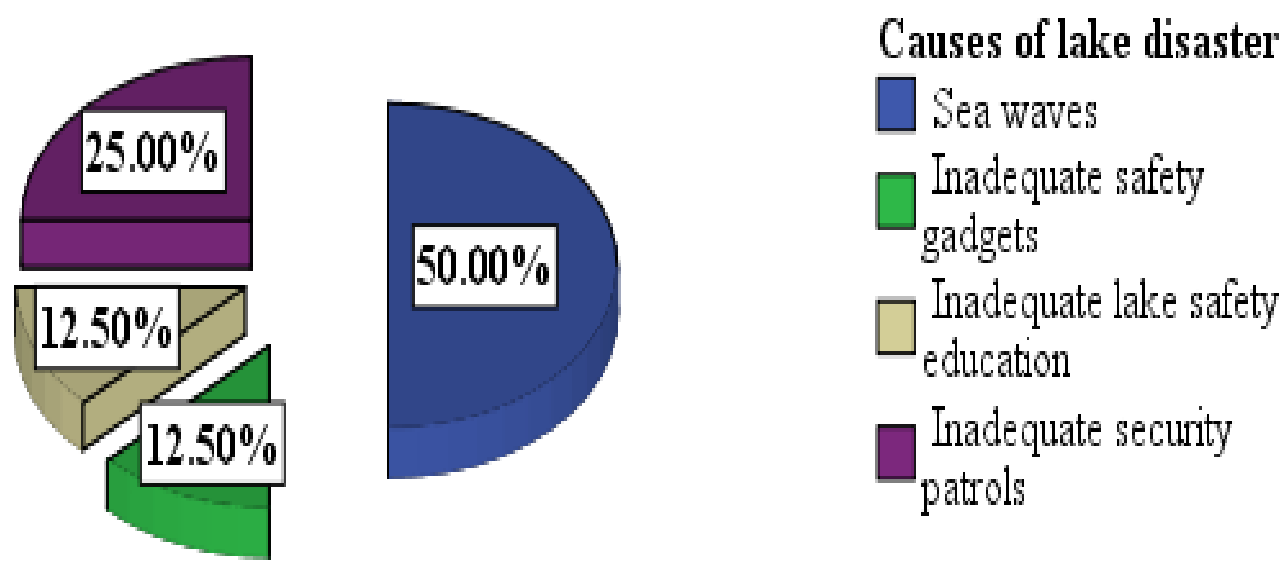

Figure 5: Causes Of Lake Hazards On Lake Victoria Source: Field Data 2014.

Figure 5 Illustrates That Most Causes Of Lake Disasters (50.00\%) As Perceived By Key Informants Were Sea Waves, 25.00\% Inadequate Security Patrols While $12.50 \%$ Indicated Lake Safety Education And Inadequate Security Patrols Respectively.

\subsection{Test Statistics}

The Researcher Conducted Spearman Correlation Between Variables On Vulnerability To Technological And Natural Hazards In The Lake With Type Of Disaster. The Results Are As Indicated In Table 4.

Table 4: Correlation Of Vulnerability To Natural And Technological Hazards With The Type Of Disaster

\begin{tabular}{|c|c|c|}
\hline \multicolumn{3}{|l|}{ Type Of Lake Disaster } \\
\hline \multirow{2}{*}{ Type Of Vessel Involved In Lake } & R- Value & -.046 \\
\hline & P- Value & .490 \\
\hline \multirow[t]{2}{*}{ Causes Of Lake Disasters } & R- Value & $.387 * *$ \\
\hline & P- Value & .000 \\
\hline \multirow[t]{2}{*}{ Major Lake Disaster Victims } & R- Value & .063 \\
\hline & P- Value & .265 \\
\hline \multirow[t]{2}{*}{ Frequency Of Lake Disasters } & R- Value & -.067 \\
\hline & P- Value & .239 \\
\hline \multirow[t]{2}{*}{ Many People Are Involved In Lake } & R- Value & -.065 \\
\hline & P- Value & .249 \\
\hline \multirow[t]{2}{*}{ Many People Need Help } & R- Value & .046 \\
\hline & P- Value & .412 \\
\hline \multirow{2}{*}{ Education On Lake Disasters Is } & R- Value & .014 \\
\hline & P- Value & .810 \\
\hline \multirow[t]{2}{*}{ Little On Lake Disaster Has Been } & R- Value & .007 \\
\hline & P- Value & .908 \\
\hline \multirow{2}{*}{ Women And Children Are Majority } & R- Value & .063 \\
\hline & P- Value & .265 \\
\hline
\end{tabular}

*. Correlation Is Significant At The 0.05 Level (2-Tailed).

**. Correlation Is Significant At The 0.01 Level (2-Tailed).

\section{Source: Field Data 2014.}

From Table 4, Causes Of Lake Disasters Indicated A Positive But Weak Correlation (.387**) With Types Of Disasters. Cross Tabulation Results Indicated That (90.4\%) Of Lake Disasters Were Caused By Weather. This 
Implies That When Lake Hazards And Vulnerabilities Increased, The Types Of Lake Disasters Increased Proportionately. Weather Hazards Were The Most Dominant Cause Of Lake Disasters. Increase In Weather Hazards Meant Increase In Lake Disasters.Type Of Lake Disasters Recorded An Insignificant Negative Correlation With Type Of Vessel, Frequency Of Lake Disasters And Number Of People Involved In The Lake Disasters. Cross Tabulation Results Indicated That 94.3\% Of The Lake Disasters Involved Boats, With 85.2\% Resulting In Drowning. 82.9\% Of The Respondents Indicated That Drowning Disasters Were Common On The Lake.The Types Of Vessels Involved In Lake Disaster Decreased With An Increase In The Types Of Lake Disasters. This Implies That As Lake Disaster Took Toll, The Types Of Vessels Involved Decreased. This Can Be Attributed To The Fact That, As The Types Of Disasters Increased, Perception Of Risk Increased And This In Turn Forced The Fishermen To Withdraw Their Vessels Or Improved Their Vessels So As To Cope With The Hazards.As The Types Of Lake Disasters Increased There Was A Corresponding Decrease In The Frequency Of Disasters. This Could Also Be Attributed To The Fact That As Disasters Increased In Frequency, There Were Interruptions In Fishing And Trading Activities On The Lake Hence Reducing The Types Of Lake Disasters.

Number Of People Involved In The Lake Disasters Decreased With Increase In The Types Of Lake Disasters. This Implies The Fishermen Perception Of Risk Increased With An Increase In The Types Of Lake Disasters. Fishermen Became More Cautious And Improved Their Local Adaptations With Increase In The Types Of Lake Disasters.

\subsection{Recommendations}

Based On The Findings Of The Study, We Recommend That:More Emphasis Should Be Placed On Community Awareness/Capacity Building On Metrological Hazards In The Lake. Emphasis Should Be Placed On Diversifying Livelihoods To Reduced Exposure To Lake Disaster Risks By The Fishermen. Any Interventions Should Focus On Cushioning Elderly Fishermen To Reduce Their Exposure To Lake Hazards. Mitigation And Adaptation Measures Targeting Disaster Risk Reduction In Lake Victoria Should Focus On Addressing The Safety Of Vessels Particularly Boats And Perception Of Risk By The Fishermen.

Any Effort To Address Disaster Risks At The Lake Should Build On The Local Adaptations Because On The Overall They Contributed To Lake Disaster Risk Reduction.

\subsection{Suggestions For Further Study}

This Study Suggests Areas Of Further Research In The Following Areas;

i. Influence On Demographic Indicators On Vulnerability Of Fishermen To Lake Disasters

ii. $\quad$ The Mediating Role Of Risk Perception In Reducing Vulnerability To Lake Disasters

iii. The Scope Of Improving Local Adaptations And Interventions By Fishermen And External Rescuers

iv. $\quad$ Further Study On Floods Forecasting And Trends Should Be Done To Assess The Flooding Situation Around The Lake.

v. Further Study Should Be Done On Wind Direction And Magnitude, So That As A Hazard Fishermen Can Be Enlightened.

\section{REFFERENCES}

[1] Abila, R.O. (2005). Impacts Of International Fish Trade: A Case Study Of Lake Victoria Fisheries. Food And Agricultural Organization Of The United Nations. Rome. Norad/Fao.Fao

[2] Byron, J. (2004). Social Vulnerability To Environmental Hazards. Social Science. Tokyo: United Nations University Press

[3] Gallopin, G.C. (2006). Linkages Between Vulnerability, Resilience, And Adaptive Capacity. Global Environmental Change 16, 293-303.

[4] Gul, S. (2010). Standard Operating Procedure For Responding To Natural Disasters. New Delhi: Government Of India.

[5] Henrik, R. (2008). 'The Eu Maritime Safety Policy And International Law'. Boston, Martinus Nijhoff.

[6] Institute Of Law And Environmental Governance. (2005). Reducing Community Vulnerability To Disaster. Last Retrieved April 17, 2013. From Http://Www.Ilegkenya.Org/Index.Php/ReducingCommunity-Vulnerability-To-Disaster2

[7] Kassim, K. (2012).The Contribution Of Lake Victoria Fisheries To The Economy Of Tanzania: Economic Research Bureau, University Of Dar Es Salaam

[8] Kenya Metrological Department (2011). Atmospheric Observations Feasibility Study For Lakevictoria.Http://Www4.Ncsu.Edu/ Seyuter/Pdfs/2011_Lake_Victoria_Atmospheric_Observ Ations_Final_Report.Pdf 
[9] Kisusu, R.W., Onyango, P.O, Haule, T. \& Salehe, M. (2012). Factors Influencing Involvement Of Local Communities In The Fishing Industry In Lake Victoria, Tanzania: From Production To Marketing

[10] Kothari, C. R. (2010). Research Methodology: Methods \& Techniques 3rd Edition. New Delhi. New Age International Publishers

[11] Mark, O. (2013, March). Maritime Communication For Safety On Lake Victoria. Kisumu, Kenya Mclaughlin, K. D. (2008). Mitigating Impacts Of Natural Hazards On Fishery Ecosystems. Retrieved

[12] May 2014, From American Fisheries Society: Http://Fisheries.Org/Shop/54064c

[13] Mugenda, O. M.\& M A. G. (2006). Research Methods: Quantitative And Qualitative Approaches.

[14] Nairobi: African Centre For Technology Studies.

[15] Mugenda And Mugenda. (2003).Research Methods: Quantitative And Qualitative Approaches.

[16] Nairobi: African Centre For Technology Studies.

[17] Nakyonyi, A. (2011). Maritime Safety On Lake Vitoria, Analysis Of Legal And Regulatory Frame Work.

[18] Oslo: Universitetet Oslo

[19] Neshikura, M. (2010). Resilient Bangladesh: Fishermen Cope With Rough Seas. Retrieved 5 4, 2014 , From Our World By United Nation University: Http://Ourworld.Unu.Edu/En/Resilient-BangladeshFishermen-Cope-With-Rough-Seas

[20] Opere, A. (2004). The Impact Of Natural Disasters, Due To Environmental Change, On The Livelihood Of The Lake Victoria Basin. Nairobi: University Of Nairobi

[21] Owili, J. K. (2006). An Overview Of Fisheries And Aquaculture In Kenya. Kisumu: Kenya Marine And Fisheries Research Institute

[22] Press, B. (2003). The Vulnerability Of Migrant Fishermen And Related Populations In Thailand.

[23] Bangokok: Raks Thai Foundation With Support From The Rockefeller Foundation.

[24] Raymond, A. (2012). Lake Victoria Fisheries Organization. Retrieved May 2, 2014, From East Africa Community: Http://Www.Lvfo.Org/Index.Php/Lvfo/Lvfo-Secretariat/5-Lake-Victoria-Fisheries-AnIntroduction

[25] Republic Of Uganda. (2010). The National Policy For Disaster Preparedness And Management. Last Retrieved September 15, 2013. From Http://Www.Opm.Go.Ug/Assets/Media/Resources/8/Disaster\%20policy.PdfRingbom, H. (2008). The Eu Maritime Safety Policy And International Law. Boston: Martinus Nijhoff.

[26] Rodrigue, D. J. P. (2013). Transportation And Disaster. Retrieved May 2, 2014, From The Geography Of Transport Systems: Http://People.Hofstra.Edu/Geotrans/Eng/Ch9en/Conc9en/Ch9c5en.Html

[27] Tromp, D.L.A.\& Kombo, D.K. (2006). Proposal And Thesis Writing, An Introduction. Nairobi: Paulines Publications.

[28] World Meteorological Organization. (2010). Partnerships In Weather, Climate And Water For Development:

[29] Yowa, Y. (2002). Natural Disaster. Retrieved May 2, 2014, From Otago Regional Council:

[30] Http://Www.Orc.Govt.Nz/Information-And-Services/Natural-Hazards/ 0713641791 